This is the accepted version of the article accepted for publication in Review of Political Economy published by Taylor \& Francis: http://www.tandfonline.com/loi/crpe20

Accepted version downloaded from SOAS Research Online: https://eprints.soas.ac.uk/23341/

\title{
Piketty’s Elasticity of Substitution: A Critique
}

\author{
Gregor Semieniuk*
}

December 11, 2016

*Economics Department of SOAS, University of London. Email: gs53@soas.ac.uk. 


\begin{abstract}
This note examines Thomas Piketty' s (2014) explanation and prediction of simultaneously rising capital income ratio and profit share by an elasticity of substitution, $\sigma$, greater than one between labor and capital in an aggregate production function. I review Piketty' s elasticity argument, which relies on a non-standard capital definition. In light of the theory of land rent, I discuss why the non-standard capital definition is a measure of wealth, not capital and is problematic for estimating elasticities. I present simple long-run estimates of $\sigma$ in the class of constant elasticity of substitution functions for Piketty's data as well as for a subset of his capital measure that comes closer to the standard definition of productive capital. The estimation results cast doubt on Piketty's hypothesis of a $\sigma$ greater than one.
\end{abstract}

Keywords: elasticity of substitution, classical theory of land rent, aggregate production function, definition of capital, Thomas Piketty

JEL codes: E13, E25, B12 
This is the accepted version of the article accepted for publication in Review of Political Economy published by Taylor \&

Francis: http://www.tandfonline.com/loi/crpe20

Accepted version downloaded from SOAS Research Online: https://eprints.soas.ac.uk/23341/

\section{Introduction}

In our view, it is natural to imagine that [the elasticity of substitution between labor and capital in a two-factor, one-commodity neoclassical growthmodel of theeconomies of 'richcountries'] waspossiblymuchless than 1in the18th-19th centuriesand becamesignificantlylargerthan 1in the20th-21stcenturies. Oneexpects ahigher elasticity of substitution in morediversified economies wherecapital can takemany forms. (Piketty and Zucman 2013, p. 36 - all pagenumbers refer to their working paper version not theQJ Eversion)

In Capital in the Twenty-First Century, Thomas Piketty (2014) explains the simultaneously rising capital-income ratio and profit share that he observes in his dataset with an elasticity of substitution greater than onebetween labor and capital in an aggregateproduction function. ${ }^{1}$ This allows him to link the rise in theamount of capital directly to functional inequality - the inequality between wage earners and those that earn returns on capital. Piketty deserves great credit for fueling the debateabout the pressingissues of incomeand wealth inequality. But hisinequality argumentbased onahighelasticityofsubstitution hasaproblem. Previousestimates of the aggregate elasticity have tended to be below one (Chirinko 2008, L'eon Ledesma et al. 2010).

Piketty goes against this evidence because he uses a non-standard definition of

\footnotetext{
'An elasticity of substitution above one implies that an increase in one input factor' s quantity relative to the other input factors into production, leads to a rise in this increased input factor' $\mathrm{s}$ share in output. Then a rising capital relative to labor input increases the capital share.
} 
This is the accepted version of the article accepted for publication in Review of Political Economy published by Taylor \& Francis: http://www.tandfonline.com/loi/crpe20

Accepted version downloaded from SOAS Research Online: https://eprints.soas.ac.uk/23341/

capital. In his view, the amount of capital equals 'all non-human assets' existing in the economy, whether used for production or not. This includes housing, land and other natural, non-produced assets, valued at their (financial) market price or imputed price. It contrasts with the standard definition of capital as produced commodities required for production (Hennings 1990), in that it includes both non-produced assets, such as land used for agriculture, and produced assets not themselves used in production, such as residential houses. ${ }^{2}$ And indeed, a considerable part of his measureofcapital isthesum of themarketprices of residential property consistingof both non-produced land and the houses on it that are no input into any production process. ${ }^{3}$ Although economists exclude residential property from measures of the capital stock in production, when they estimate the parameters of production functions (for instance Antras 2004), Piketty includes it. To better distinguish Piketty's from the usual notion of capital, I will call Piketty's non-human assets 'wealth', and the stock of produced assets from cumulated investment expenditures 'productivecapital' in thisarticle.

Thisfinancial wealthmeasure, when usedinstead of productivecapital, maybias theelasticity of substitutionupwards. Below, I will makethisargumenttheoretically based on the concept of land rent. But it is also intuitively obvious. It isnowhere better illustrated than with the subprime housing bubble in the US, where the

\footnotetext{
${ }^{2}$ Production is here narrowly defined as production in firms and government through its direct inputs. It excludes the great amount of unpaid labor expended in the household and elsewhere on the reproduction of the labor force.

${ }^{3}$ National accounting rules add to the confusion by imputing a rental income to owner-occupiers of houses in order to ensure national income comparability between countries with commercial rental markets of varying importance. Thus, within this accounting framework, houses produce 'housing services' (United Nations et al. 2009, p. 99).
} 
This is the accepted version of the article accepted for publication in Review of Political Economy published by Taylor \& Francis: http://www.tandfonline.com/loi/crpe20

Accepted version downloaded from SOAS Research Online: https://eprints.soas.ac.uk/23341/

valueof houses roseconsiderably beforedroppingin the2008financial crisis. These fluctuationsin house prices had no (direct) impact on thestock of productivecapital available for production. Hence, wealth fluctuated more over time than productive capital. But since the elasticity of substitution is greater the more the capital stock changes relative to a given changein the rate of return, the elasticity of substitution calculated based on wealth is in that case bigger than that calculated based on productive capital. ${ }^{4}$ It is not clear how big because Piketty appears not to report quantitative estimation results. From inspection of the data, however, he mentions a range of 1.3 to 1.6 for the elasticity of substitution between wealth and labor in present times high income economies (Piketty 2014, p. 221). Any value above oneallows him to explain thesimultaneousincreasein the wealth-incomeratio and wealth share with neoclassical growth theory. Since, as Robert Rowthorn (2014) points out, the high value of the elasticity is the pivot on which Piketty's theory of therisingwealth shareinincomehinges, itisinterestingtounderstand theargument and data better.

In this paper I will review Piketty's elasticity argument and then discuss it critically in light of his non-standard capital definition by drawing on insights from thetheoryoflandrent. Then, assuminganeoclassical productionfunction asPiketty does, I will makea simple quantitative estimate of the elasticity of substitution for the data used by Piketty as well as for a subset of his wealth measure that comes closer to the definition of productive capital. The estimation results cast doubton the hypothesis of an elasticity of substitution greater than one even for Piketty's

\footnotetext{
${ }^{4}$ See James Galbraith (2014a) on the problem of using a financial measure of capital and Galbraith (2014b) on how the valuation of financial assets influences Piketty' s accounting.
} 
idiosyncratic capital definition.

\section{Piketty's Elasticity Argument}

Piketty's (2014) discussion of the elasticity of substitution is based on the paper by Piketty and Gabriel Zucman (2013). ${ }^{5}$ In Section 7 of Piketty and Zucman they observe that both the wealth/income ratio, $W / X$ or $\beta$ in their notation, and the wealth share in income, $\alpha$, have risen in high income countries, while the rate of return on wealth, $r=\alpha / \beta$, has fallen slightly. ${ }^{6}$ Then they write (recalling that what they call capital, I call wealth here)

Of course, thisdecline[in r] is whatonewould expectin anymodel: when there is more capital, the rate of return to capital must go down. The interesting question is whether it falls more or less than the quantity of capital. According to our data it has fallen less, implying a rising capital share. (ibid. p. 34)

They must mean whether the rate of return falls more than proportionally to the rise in the wealth-output ratio, $\beta$, since $\alpha=r \beta$.

Operatingin aneoclassical model of growth, they then assert that thisobservation can be explained by a two factor, one commodity production function, with the peculiar input factor of what I call here wealth - which Piketty of course conflates withcapital. Theonlyadditional restriction on themodel isanelasticityof substitution

\footnotetext{
${ }^{\mathbf{5}}$ Now published in abbreviated form in the Quarterly Journal of Economics.

${ }^{6}$ Their data appendix includes files on eight countries: Australia, Japan, Canada, USA, France, Germany, Italy and UK.
} 
greater than one, which implies precisely that a rise in wealth leads to an increase in its share in output. This is because it can be substituted for labor so well, i.e. the additional units of wealth 'in production' lead to almost as much additional output perunit wealthasfor thepreviously existingunits of wealth (whateconomistswould call the marginal product of wealth.) Since by assumption the rate of return on wealth equals its marginal product, the additional units of wealth add more to the income of wealth owners than the diminished return per unit wealth reduces it and the total remuneration of wealth owners increases relative to that of labor. ${ }^{7}$

Piketty and Zucman highlight that their explanation is more parsimonious than alternative models with imperfect competition or with three input factors: skilled and unskilled labor and wealth (ibid. p. 35). Stressing that their 'discussion of capital shares and production functions should be viewed as merely exploratory and illustrative' (p. 36) they nevertheless predict that it is likely that $\alpha$ will rise to above $40 \%$ because of a strong growth in $\beta$ as it returns to its value of the 18-19th centuriescombined with an elasticity of substitution greaterthan one. Acceptingfor the present analysis the theoretical assumptions advanced by Piketty and Zucman except theirnon-standard definition of capital, I will discuss howthisnon-standard definitionmayimpact theelasticityof substitution betweenlaborandtheso-defined capital.

\footnotetext{
'Of course it should be kept in mind that Piketty and Zucman' s notion of wealth as an input into production is inconsistent also with the neoclassical notion of capital (Garbellini and Wirkierman 2014).
} 


\section{The Definition of Capital}

An elasticity greater one between input factors into production stands in contrast with most previous empirical work, but is likely an artifact of a non-standard definition of capital. PikettyandZucman prefertheirall non-human asset definitionforcapital becauseitisconsistent with balancesheetestimates ofwealth(2013, p. 6- 7), because housing assets make up half of national wealth and some housing may be used for business purposes (ibid. p. $12 \mathrm{fn}$. 17) and because it 'is precisely what the economists of theeighteenth and nineteenth century aimed to capture.' (ibid.p. 7, my emphasis) In particular, according to them the lack of balance sheet data was a majorreason whyeconomistsfrom Cambridge, U.K., tookissuewith theproductionfunction used by the Cambridge, Massachusetts, economists in the so-called Cambridge capital controversies. With the new data they presumably would not do so. ${ }^{8}$ Piketty and Zucman believe that the non-standard definition of capital 'is a useful, meaningful, and well-defined starting point' (ibid.) for analyzing models of growth and distribution and the elasticity of substitution, even though it represents wealth, not productive capital.

\subsection{Empirical differences}

In how far is the empirical evolution of the wealth-income ratio different from the productive capital-income ratio? Stefan Homburg (2014) shows for France that

\footnotetext{
${ }^{8}$ Piketty and Zucman do not explain how exactly this would have resolved the debate. Galbraith (2014a) discusses problems with Piketty' s (2014) depiction of that debate; for an account of how the debate went see Harcourt (1972) and, for a opposing view, Stiglitz (1974). More recent discussions can be found in Cohen and Harcourt (2003) and Pasinetti (2003).
} 
it is thanks to the non-standard definition that Piketty's wealth-income ratio is increasing. The revaluation ofland and real estate, but not the accumulated capital used in production grewat afaster ratethan income. In other words, whilePiketty's wealth has increased morethan proportionally with income, productive capital has increased proportionally with incomein France, in accordancewith thefourth of the Kaldor (1961) stylizedfacts.

Figure 1shows that taking out thereal estateand foreign capital parts of Piketty's measureof wealth thatisrepresented bydashedlines, theremaining 'otherdomestic capital' series that is represented by solid lines has no or much less upward trend for the eight countries for which Piketty provides data. 'Other domestic capital' is a financial valuation, too, and subject to revaluation that may have little to do with a change in value at cost of the underlying capital. But it approximates productive capital better by excluding residential housing that is not used for production, and thenon-produced land it stands on. The time series confirm that the changes in the wealth-income ratio are larger than those in the other domestic capital-income ratio.

\subsection{The Theory of Land Rent}

Thetheoreticalsupportforwealthasamonolithicinputintoproductionisquestionable. It is curious that Piketty calls on the 18th-19th century political economists of the English classical school to back up his argument of subsuming all assets that constitute wealth under the narrower term capital. The classical economists, particularly Adam Smith, David Ricardo and their critic, Karl Marx, distinguished between capital and land. According to their labor theory of value, labor creates value in 
Figure 1: Annual time series of the ratio of wealth to national income, W/Y, dashed lines, and of productive capital (approximated by data on 'other domestic capital') to national income, $\mathrm{K} / \mathrm{Y}$, solidlines, for eight countries. For someseries, datais only available from 1970. The data sources are in the data appendix.

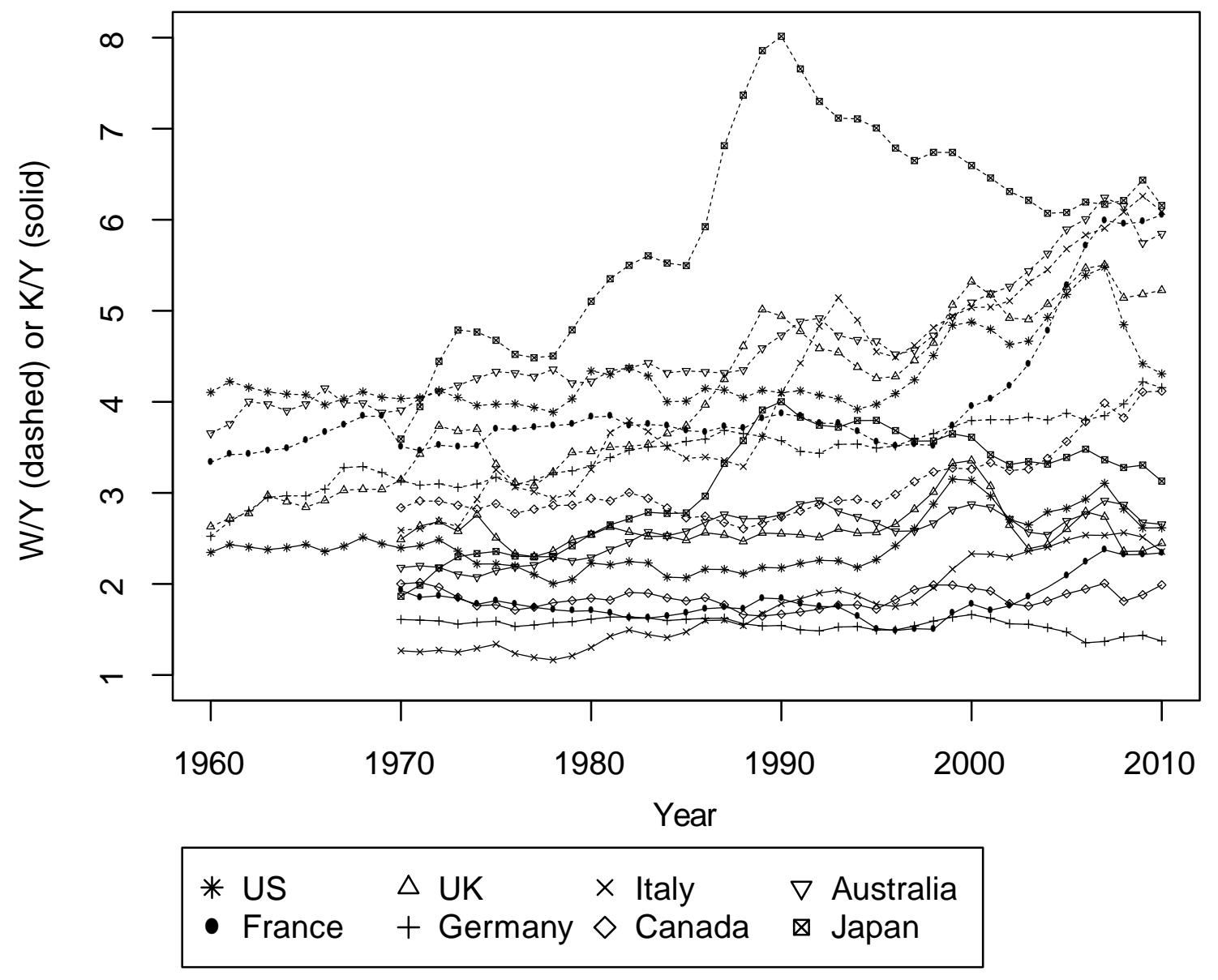

theform of commodities. Someof thecommoditiesproduced in a certain period are notconsumed butaccumulated as capital for production in future periods. Capital's value (and price) arises from its cost of production, which is a function of thelabor used in production. The owners of capital can claim part of the money against which the valuable commodities exchange in the form of profits. The rate of profit 
This is the accepted version of the article accepted for publication in Review of Political Economy published by Taylor \& Francis: http://www.tandfonline.com/loi/crpe20

Accepted version downloaded from SOAS Research Online: https://eprints.soas.ac.uk/23341/

is the quotient of the flow of profits and the stock of capital that capitalists have accumulated for production.

A class of non-produced and hence non-accumulated assets of which there is a limited and scarce supply, called land, on the other hand, does not earn profits. Instead, owners of scarce land assets earn a rent thanks to their ability to exclude others via property rights from the freeuse of theland asset for production. ${ }^{9}$

Conceptually, assets of land type are not limited to the domain of agricultural land. Theymaytaketheformofariverforelectricitygeneration, oilreserves, housing for workers close to a factory, but also rights to financial or legal intermediation or patents. ${ }^{10}$ The unifying principle is that property rights exist that make a resource, which is used in production, scarce.

Land asset owners appropriate part of the value created by labor with the aid of capital. Ostensibly in Piketty, a rise in the price of land and, consequently, a rising wealth-income ratio is interpreted as being caused by substitution of moreland for labor. But following the classical economists, this does not imply that more land is harnessedforproduction- bydefinitionlandisscarceandlimited. Rather, itimplies that the price of land increases relative to the labor share. It is a consequence of a revaluation of scarce land, not an increase in its quantity.

The reason why the price of land changes may instead be a change in the rate of

\footnotetext{
'The credit of distinguishing rents from profits (and wages) systematically goes to Adam Smith, and he identified rent as arising from a monopoly on land (Smith 1904, book 1, chapter 11). David Ricardo (1951, chapter 2) explained 'differential rent' as arising from different qualities of land in use, and Karl Marx analyzed the possibility of 'absolute rent' on all land assets regardless of quality if the sector is more labor intensive and so produces relatively more surplus value than other sectors, part of which can be appropriated by land owners (Marx 1991, in particular chapter 45).

${ }^{\mathbf{1}}$ Foley (2013) discusses modern manifestations of the old concept of rent in financial and information services.
} 
return on produced assets. Land, likeany other asset, can be sold on themarket. Its market price (that goes into Piketty's wealth) is determined by what rate of return it can earn. With competitive markets, land assets earn on average the rate of return that produced assets, that is productive capital, in the same risk class earn. The rate of return on land is expressed as

$$
\text { rate of return }=\frac{\text { rent }}{\text { price ofland }}
$$

however, the causal direction does not go from right to left. On the contrary, therate of return on assets is determined by the return on productivecapital, and therent of land determined by its scarcity. Therefore, land is capitalized at a price that results from theratio of the two and the price of land is the result of separately determined rent and rates of return.

$$
\text { price of land }=\frac{\text { rent }}{\text { rate ofreturn }}
$$

Iftheamountofland assetsremainsconstantand therateofreturn on productive capital falls, then the price of that land - its capitalization - must increase, so as to keep the rate of return on land equal to that on produced assets. Otherwise there would be an arbitrage opportunity. These increases are large, relative to the percentage change in the rate of return. A change in the rate of return from $11 \%$ to $10 \%$ induces a ten percent rise in the price at which land is capitalized, a change from $6 \%$ to $5 \%$ even a twenty percent increase. As a consequence, the value of land 
This is the accepted version of the article accepted for publication in Review of Political Economy published by Taylor \& Francis: http://www.tandfonline.com/loi/crpe20

Accepted version downloaded from SOAS Research Online: https://eprints.soas.ac.uk/23341/

increases, and so does a measureof wealth, whichincorporates it.

Although neoclassical economics has abandoned the labor theory of value, the concept of rent on scarce resources is widely used..$^{11}$ The narrower definition of productive capital based on which economists have estimated the elasticity before Piketty, recognized theimportant distinction between capital that earnsa profit and land that earns a rent, and focused on accumulated capital only.

\subsection{Elasticity Measurement Consequences}

Onearea wherethistheoretical reasoningappliesistheresidential propertymarket, which is not only built on scarce land, but is additionally not used in production. Hence, forasignificantpart of wealth, thereforecausalityrunsfromtherateof return to its capitalization, according to the theory just laid out. This line of reasoning contradicts Piketty's theory where large swings in the wealth measure are said to cause changes in the rate of profit. However, failureto distinguish land from capital may lead to inflated elasticity estimates. Since the elasticity of substitution is an increasingfunction of the rate of change in capital output ratio; wealth measures of capital that includeland assets's changes in their market valuation will tend to bias elasticity estimates upwards.

Looking at the Piketty and Zucman data it seems that capital has increased enormously relative to income and labor, while the rate of return has only fallen

\footnotetext{
' 'Schumpeter 1954, p. 642. Neoclassical treatments of rent on land or scarce resources motivated by utility maximization considerations of scarce resource owners can be found in textbooks on resource economics, e.g. Fisher(1981) or Randall and Castle (1985). Randall and Castle also discuss 'capital gains on land' when land assets of different quality exist and new land of lower quality is taken up for production.
} 
This is the accepted version of the article accepted for publication in Review of Political Economy published by Taylor \& Francis: http://www.tandfonline.com/loi/crpe20

Accepted version downloaded from SOAS Research Online: https://eprints.soas.ac.uk/23341/

slightly. In reality part of it may be a revaluation of the capitalized land. AsFigure 1 above shows, the actual underlying productive capital may have changed little, which leads to the conjecture that the elasticity measure discussed in Piketty and Zucman'spaperisinflated. In therest of thisnoteI will compareempirical estimates of theelasticity of substitution using wealth and the other domestic capital measure as a proxy for productive capital.

\section{Estimatingthe Elasticity of Substitution: Method and Data}

Estimating the elasticity of substitution has a long tradition in econometrics, and whileresults are varying, a majority of existing estimates is below one. ${ }^{12}$. I havenot found any existing estimates of the elasticity of substitution for the eight country PikettyandZucman dataset. Consistentlywiththeirdescription of agrowthmodel, I basemyestimateon theconstantelasticityofsubstitution(CES) productionfunction with constant returns to scale and Hicks-neutral technical change. It admits the derivation of a linear relationship between the logarithm of the rate of returnand thelogarithm of thecapital outputratio, wheretheslopeof thefitcan beinterpreted as the elasticity of substitution between capital and labor. The derivation is in the

\footnotetext{
${ }^{12}$ Table 1 in Lé on-Ledesma et al. (2010) list studies with estimates using aggregate data, Chirinko (2008) discusses specifically long-run estimates, and also lists firm level data estimates. Berndt (1983, ch 9), recounts the influence of the elasticity of substitution on the development of different types of production functions.
} 
Mathematical Appendix. I estimate the two equations

$$
\begin{aligned}
& \log \frac{W_{t}}{X_{t}}=-\sigma_{W} \log \left(r_{t}\right)+c_{W}+E_{t} \\
& \log \frac{K_{t}}{X_{t}}=-\sigma_{K} \log \left(r_{t}\right)+c_{K}+\varepsilon_{t}
\end{aligned}
$$

for the wealth and the productive capital proxy measure, where $\sigma_{W}$ or $\sigma_{K}$ is the elasticity of substitution and $r$ is the rate of return. $c$ comprises constant factors that determine thewealth/incomeratio, $E$ and $\varepsilon$ are error terms.

Piketty discusses long run trends. While the data is scarce, I am applying standard techniques from other recent work on the long run value of theelasticity of substitution, that aim at controlling for cyclical variations, to find out what these estimates suggest for the Piketty Zucman data. Chirinko (2008) presents three methods of long-run trend estimation. The first assumes that the annual values in equations (1) and (2) are close to their long-run values, the second attempts a cointegration approach (if this relationship exists) adding lead and lag first difference terms, and the third method divides the period in two sections, takes the average values in each and calculates the rate of change between periods. The single rate of change between the two periods is then estimated in a cross section. The last approach is only applicable to a panel with a sufficiently large number of countries, which is not the case for the eight countries under consideration here. I will implement thefirst two approaches below.

Theestimation requires data series for wealth, $W$, productivecapital, $K$, output, $X$, and the rate of return on capital $r$. Data for $W$ is the capital series used by 
Piketty, which I call wealth here. $K$ is approximated by his 'Other domestic capital' series, which excludes housing wealth. Thedataseries for both definitions of capital for the USareavailable for 1960-2010, for the seven other countries for 1970-2010, limiting the time series to 51 observations for the US and 41 for all others. While these annual series are short, they also correspond to the time period during which Piketty claims the elasticity may have been higher than before. With $X$ the 'net national income' series used by Piketty, this yields the two time series $W / X, K / X$. I will use Piketty's 'capital share excluding government interest earned' series that is also used by Piketty (2014, technical appendix p. 36), and label it $\alpha$ following his notation. Then, like in Piketty, the rate of return on weatlh is computed by multiplying $W / X$ by the share of capital incomes, $r=\alpha$.

The precise data sources are in the Data Appendix. The data are problematic. First, they are in nominal terms. Hence, changes in thecapital/ output ratio may be distorted due to differently changing priceindices. Absent price deflators for any of the capital time series, I am using the available data. Second, they are in net terms. For Britain, gross data is available, and I use it to compare results. Third, there is no data to proxy technical change. The data can hardly be used for estimating results comparable with previous estimates. However, the estimates that use only the data available with Piketty and Zucman can be used to check the consistency of their claims with their own data. 
This is the accepted version of the article accepted for publication in Review of Political Economy published by Taylor \& Francis: http://www.tandfonline.com/loi/crpe20

Accepted version downloaded from SOAS Research Online: https://eprints.soas.ac.uk/23341/

\section{Discussion of Results}

Thelog-log plots in Figures 2 and 3 plot all data for each of the eight countries. The rate of return to wealth is on thex-axes, the wealth income and productive capital incomeratios on they-axes. Dots showdata using wealth, and circles data using the productive capital proxy. Thex-axis scale varies from plot to plot, they-axis scale is the samethroughout for comparison, except forJ apan, which has somedata points with $W / X>7$. The wealth data areabove the productive capital data due to their largernumerator. The wealth datais also moretilted, as was expected dueto the largerchanges in the wealth output ratio discussed above. 
Figure 2: Scatter of annual observations of wealth-income (disks) and productive capital-income (circles) ratios against the rate of return, and linear fits. Scales on both axes are logarithmic.
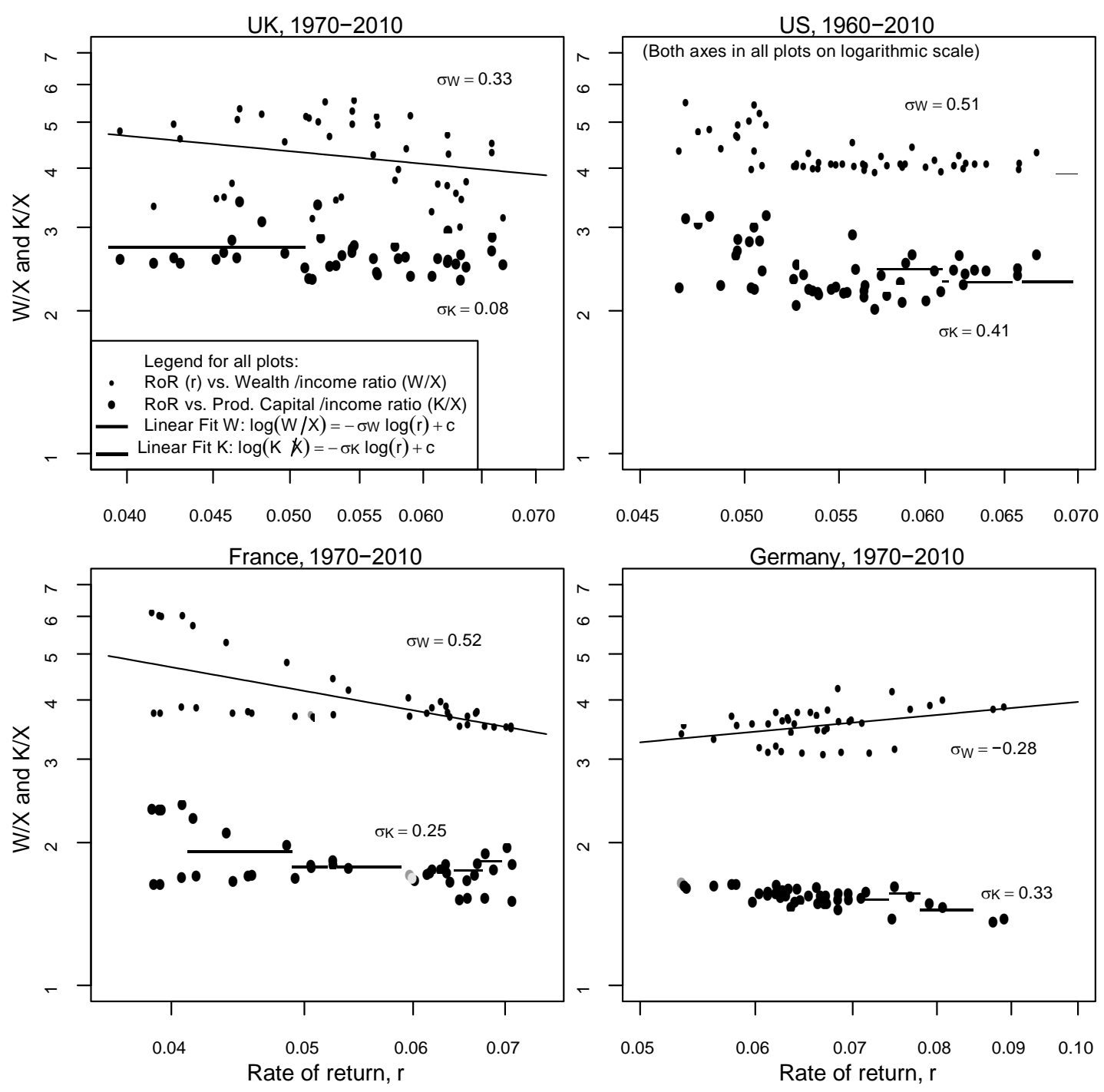
Figure 3: Scatter of annual observations of wealth-income (disks) and productive capital-income (circles) ratios against the rate of return, and linear fits. Scales on both axes are logarithmic.
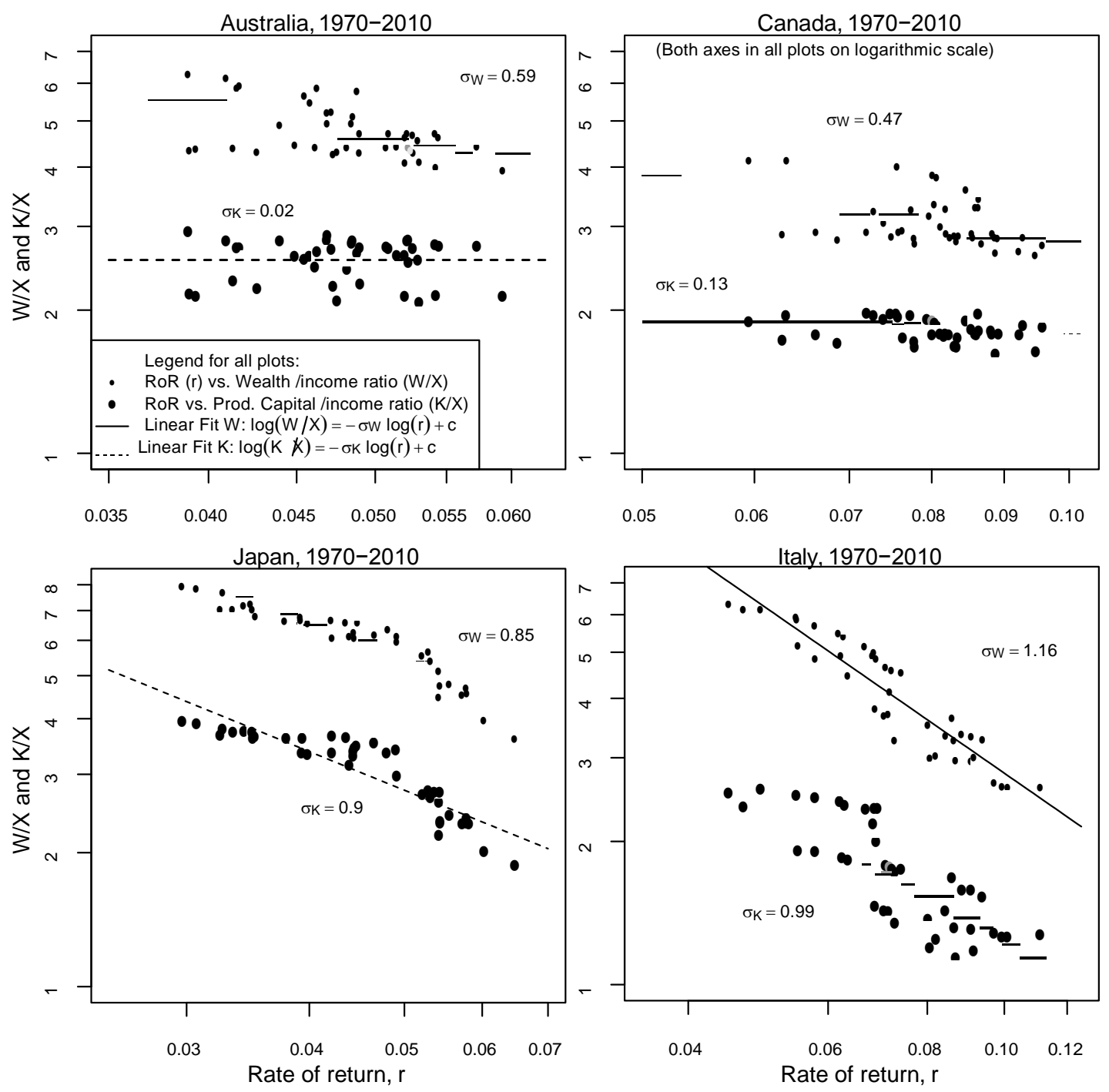


\subsection{Ordinary Least Squares}

Figures 2 and 3 also plot linear fits, where the slope is the negative of the elasticity of substitution point estimate of an ordinary least squares (OLS) cross section regression. For wealth the $\sigma$ point estimate is below one, often below 0.5 , while Germany appears anomalous. For the productive capital estimate, the elasticity drops further everywhere except in J apan. Germany nowshows a positive but small elasticity of substitution. Looking also at the standard errors of the estimates in Column 1 and 2 of Table 1 for wealth and productive capital, in spite of the small sample size the unit elasticity is outside and above the confidence interval of any of the estimates besides Italy. In fact, the lack of statistical significance of several estimatestestifiestotheelasticitybeingclosetozero forseveral countries: Australia, Canada and the UK.

MattRognlie(2014) offers an explanation for these surprisingly lowelasticities, by highlighting that Piketty's discussion is in net of depreciation terms and that for net quantities the elasticity of substitution is lower than for gross quantities, since the depreciation is paid for out of profits and not labor income. The 'Gross vs. Net Appendix' at thevery end of the document illustrates Rognlie's logical argument at theexampleof Britain, which generates a higher $\sigma$ estimatewhen using gross output and capital share. Yet, precisely because the discussion is about net quantities, the results discussed hereare the ones of interest that check Piketty's theory.

As is usual with time series data, however, there is significant serial correlation. TheDurbin-Watsontestrejectsthenull of noserial correlation for everysingleseries. The OLS estimate is inefficient. While first-differencing is a less helpful remedy as 
it removes long-run information in the data, generalized least squares (GLS) can theoretically correct for serial correlation.

\subsection{Feasible Generalized Least Squares}

Since the autocorrelation structure is unknown, the elasticity has to be estimated using feasible GLS (FGLS). Following Antras (2004), I regress the residuals of the estimates on up to their first four lags, that is $E_{t}={ }^{)}{ }_{j=1} E_{t-j}+v_{t}, J=1,2,3,4$, to check whether the error term $v$ is whitenoise. I stop when Ljung-Box tests with one to five lags cannot reject the null hypothesis of the error term, $v$ being white noise at the five percent confidence level in at least four of the five test specifications.

Most FGLS regressions admit of an $\mathrm{AR}(1)$ structure but some are $\mathrm{AR}(2) .{ }^{13}$ The results are reported in columns 3 and 4 of Table 1 . The elasticity estimates for the wealth series drop dramatically in every series; yet they are all significant due to lower standard deviations of the estimator. The picture is more mixed for the productive capital proxy, as some estimates rise, others fall. The ones that rise, however, are those where the OLS estimate could not reject the hypothesis of zero elasticity. In the FGLS estimate, every single elasticity is signficantly different both zero and one, and all but one estimate are below 0.5. While these estimates are subject to the data caveats above as well as the very small sample size, they do not support Piketty's hypothesis of an elasticity significantly greater than one. It

\footnotetext{
${ }^{13}$ Those which use an AR(2) autocorrelation structure are both US regressions, the French wealth regression, and the German, Australian and Italian productive capital regressions. The German productive capital series only reports white noise with a surprising AR(4) structure. The UK wealth series suggests an $\mathrm{AR}(2)$ correlation structure, however the restricted maximum likelihood algorithm does not converge, so I estimate a compromise AR(1) instead. The computations are done using the $\mathrm{R}$ function $\mathrm{gls}()$ in the nmle package.
} 
Table 1: Estimates

\begin{tabular}{|c|c|c|c|c|c|c|}
\hline & $\begin{array}{c}\text { Col } 1 \\
\text { OLS } w\end{array}$ & $\begin{array}{l}\mathrm{Col} 2 \\
\mathrm{OLS}_{K}\end{array}$ & $\begin{array}{c}\text { Col } 3 \\
\text { FGLS } w\end{array}$ & $\begin{array}{c}\text { Col } 4 \\
\text { FGLS }_{K}\end{array}$ & $\begin{array}{l}\mathrm{Col} 5 \\
\mathrm{CI}_{w}\end{array}$ & $\begin{array}{l}\mathrm{Col} 6 \\
\mathrm{CI}_{K}\end{array}$ \\
\hline \multirow[t]{2}{*}{ UK } & 0.3344 & 0.0779 & $0.2031 * *$ & $0.2364 * *$ & & \\
\hline & (0.2049) & (0.0961) & (0.0616) & (0.0735) & & \\
\hline \multirow[t]{2}{*}{ US } & $0.5138 * *$ & $0.4055 *$ & $0.3573 * *$ & $0.3877 * *$ & & \\
\hline & $(0.1044)$ & $(0.1684)$ & $(0.0631)$ & $(0.0894)$ & & \\
\hline \multirow[t]{2}{*}{ FR } & $0.5177 * *$ & $0.2522 * *$ & $0.1767 * *$ & $0.1568 * *$ & & $0.2035 *$ \\
\hline & $(0.09625)$ & $(0.07968)$ & $(0.0427)$ & $(0.0739)$ & & $(0.0824)$ \\
\hline \multirow[t]{2}{*}{ DE } & $-0.2831 *$ & $0.3282 * *$ & $0.1598 * *$ & $0.2250 * *$ & $-0.4273 * *$ & $0.2818 * *$ \\
\hline & $(0.1096)$ & $(0.0486)$ & $(0.0409)$ & $(0.0522)$ & (0.0989) & $(0.0565)$ \\
\hline \multirow[t]{2}{*}{$\mathrm{AU}$} & $0.5859 * *$ & 0.0187 & $0.2622 * *$ & $0.2808 * *$ & & -0.3173 \\
\hline & $(0.1672)$ & (0.1564) & $(0.0407)$ & $(0.0390)$ & & $(0.2123)$ \\
\hline \multirow[t]{2}{*}{$\mathrm{CA}$} & $0.4719 * *$ & 0.1307 & $0.2086 * *$ & $0.1780 * *$ & & -0.0455 \\
\hline & $(0.1575)$ & $(0.0792)$ & $(0.0432)$ & $(0.0621)$ & & $(0.1290)$ \\
\hline \multirow[t]{2}{*}{ JP } & $0.8532 * *$ & $0.8985 * *$ & $0.4884 * *$ & $0.4116 * *$ & $0.9240 * *$ & $0.9560 * *$ \\
\hline & $(0.0551)$ & 0.0684 & $(0.0731)$ & $(0.0684)$ & $(0.0608)$ & $(0.0783)$ \\
\hline \multirow[t]{2}{*}{ IT } & $1.1597 * *$ & $0.9910 * *$ & $0.5550 * *$ & $0.3033 * *$ & $1.3830 * *$ & $1.2764 * *$ \\
\hline & $(0.0747)$ & $(0.1073)$ & $(0.0438)$ & $(0.0708)$ & $(0.0826)$ & $(0.1147)$ \\
\hline
\end{tabular}


remains to be seen whether series are non-stationary and the regressions spurious or additionally cointegrated, and therefore permit using the other method of estimating thelong-run elasticity discussed in Chirinko (2008).

\subsection{Cointegration}

The OLS and GLS results may be spurious if the time series used havea stochastic trend. To test for unit roots, augmented Dickey-Fuller tests with one and two lags are run on each of the three time series for every country. For every series but that of the UK rate of return, at least one specification cannot reject the hypothesis that theseries is integrated of order one. Applying theEngleGranger (1987) approach, a furtherDickey-FullertestusingtheMacKinnon(1996) criticalvaluesontheresiduals of theOLSregressorsrevealsthat forabouthalf of theseriestheerrorsarestationary. Forthese, the OLSestimateis thereforethat of along-run relationship, whilefor the others the hypothesis of a spurious regression cannot be rejected. FollowingChirinko (2008), addinglags and leads of the differences of thelogarithm of therateof return to equations (1) and (2) controls for deviations of observed values from thelong-run unobserved ones that distort the long-run elasticity estimate. In light of the small data sample, onlyleadswereadded. ${ }^{14}$ ThisreflectsPikettyandZucman's theoretical presumption that changes in the input ratios impact the rate of profit, and that this may happen with a lag. Hence, adding leads can be interpreted as controlling for multiyear fluctuations in therate of profit and highlightinginstead thelonger-term response in returns to a change in the capital labor (and capital output) ratio.

\footnotetext{
${ }^{\mathbf{1 4}}$ Adding leads instead lags or a combination of both did not produced similar results.
} 
Estimates with threeleads are reported for those regressions where a cointegration relationship was detected in columns 5 and 6 of Table 1. While estimates for France andGermanyin theproductivecapital seriesaresmallerthantheircointegratedOLS estimates, all four estimates forJ apan and Italy increase. ForJ apan, thehypothesis of a Cobb-Douglas specification cannot be rejected, and the estimates for Italy are significantly above unit elasticity. These results suggest that at least for a few series there are long-run stationary relationships, all but one of which result in estimates of the elasticity of substitution that are below or not above unit elasticity, again countervailing Piketty's hypothesis.

All of theresultsshould beinterpreted with greatcaution. First, thereisthesmall sample size. Then the counterintuitive negative parameters both in the German estimates across columns and (insignificant) Canadian and Australian estimates in the cointegration column 6 , suggest that the capital output ratio and rate of return may be linked in complicated ways over time, whereby an elasticity with the 'right' sign may only occur between observations several years away from each other. Whilethecointegration estimates withleads go somewaytowardscontrolling for the cyclical component in rates of return, it may fail to capture intertemporal feedback between the series due to technical change. Changes in capital intensity may influence the rate of return with a lag, but conversely the rate of return and itsinfluence on thecapital sharemay havea repercussion on subsequent changes in capital intensity, what is known as induced technical change (Kennedy 1964). The endogeneity problem that this poses for a regression analysis may bias theresultsin either direction (Antras 2004), making it hard to judge in whether elasticity estimates 
maybeoverorunderestimated.

Yet, with these caveats noted, nothingin theresults suggests that an appropriate range for $\sigma$ is between 1.3 and 1.6, as claimed by Piketty. On the contrary, the low estimates reported here for his own data and idiosyncratic definition of capital that is expected to produce higher elasticity estimates than thestandard productive capital measure, suggests that his prediction of how capital shares will evolve must be treated with suspicion. Since Piketty's claim of a high elasticity goes against most previous evidence, he would need to have particularly clear results of above unit elasticity. But the foregoing analysis indicates that it would be very difficult to obtain such clear cut results.

\section{Conclusion}

Thomas Piketty's empirical and analytical brilliance in his sweeping history of income and wealth inequality at the micro-level is remarkable. However, his elasticity of substitution theory of a rising capital share relying on a 'wealth' measure of capital at the macro-level is both theoretically and empirically unconvincing. In light of the theory of rent, some of the changes in his wealth measure that heconflates with capital are likely to reflect revaluations in the capitalization of assets of land type. These, rather than reflecting additional capital employed in production, are caused by changes in the rate of return itself and may overstate not only the rise in the capital output ratio but also estimates of the elasticity of substitution. Empirically, even ifoneuseswealthinstead ofastandard capital definition forthecapital/income 
ratioand thusrisksinflatingelasticity estimates, hisown datasetdoesnotsupportan above unit elasticity. Ridding the capital measure from housing assets further adds to the evidence against a high elasticity. While the econometric estimates are not conclusivefor settlingonanyparticularelasticityvalues, Pikettywillneed toproduce better evidence for his theory to be covincing. In the meantime, other macroeconomic argumentsthatdo notrelyon atechnogical 'productionfunction' explanation- such as advanced in Rowthorn (2014), Taylor (2014) and Barbosa-Filho (2016) - will be needed to grapple with the rising capital share and the inequality it implies. It is to Piketty's great credit that he has fueled the debate about this pressing issue.

\section{Acknowledgements}

This research was carried out whiletheauthor was at theDepartment of Economics, New School for Social Research. It arose out of discussions with Duncan Foley, Lance Taylor and Thomas Michl. Their comments and those by Isabella Weber, Philip Mader,J ang Ho Yangand two anonymous refereesimproved earlierversions. By making their data available on the web, Thomas Piketty and Gabriel Zucman enabled the empirical estimates in this note. This work was supported by a grant from theInstitutefor New Economic Thinking to theSchwartz Center for Economic Policy Analysis, New School for Social Research. The author declares no conflict of interest. 


\section{Literature Mentioned}

Antras, Pol. TstheU.S. aggregateproductionfunction Cobb-Douglas? Newestimates of the elasticity of substitution.' Contributions to Macroeconomics 41: 1- 34 .

Barbosa-Filho, Nelson. 2016. 'Elasticity of substitution and social conflict: a structuralist note on Piketty's Capital in the 21st Century.' Cambridge Journal of Economics 40: 1167- 1183. DOI: $10.1093 / \mathrm{cje} / \mathrm{bev} 042$

Berndt, Ernst. 1983. The practice of econometrics: classic and contemporary. Reading, MA: Addison-Wesly.

Chirinko, Robert S. 2008. ' $\sigma$ : The Long and Short of It.' Journal of Macroeconomics 30 2, 671-686.

Cohen, Avi J. and Geoffrey C. Harcourt. 'Retrospective: Whatever Happened to the Cambridge Capital Theory Controversies?' Journal of Economic Perspectives 17 1: 199- 214.

Engle, Robert F. and Clive W. Granger. 1987. 'Co-Integration and Error Correction: Representation, Estimation, andTesting.' Econometrica 552: 251- 276.

Fisher, Anthony .C. 1981. Resource and environmental economics. Cambridge: Cambridge University Press.

Foley, Duncan K. 2013. 'Rethinking Financial Capitalism and the “Information” Economy.' Review of Radical Political Economics 453: 257- 268.

Galbraith, James. 2014a. 'Kapital for the Twenty-First Century?' Dissent Magazine, Spring 2014.

http://wWw. dissentmagazine. org/article/kapital-for-the-twenty-first-century

Galbraith, J ames. 2014b. 'Unpacking the First Fundamental Law.' http:// 
economistsview. typepad. com/economistsview/2014/05/unpacking-the-first - fundamental-la html

Garbellini, Nadia and Ariel L. Wirkierman. 2014. 'Piketty Versus Pasinetti: A Comment on Taylor.' International Journal of Political Economy 43 3: 35- 43. DOI: 10.1080/08911916.2015.1001664

Harcourt, Geoffrey. C. 1972. Some Cambridge Controversies in the Theory of Capital. Cambridge: CambridgeUniversity Press.

Hennings, K H. 1990. 'Capital as a Factor of Production.' In Capital Theory edited by J ohn Eatwell, Murray Milgate and Peter Newman, 108- 122. New York and London: W.W.Norton.

Homburg, Stefan. 2014. 'Critical RemarksonPiketty's “Capital in theTwenty-first Century".' Uni Hannover Discussion Paper No. 530.

http://www3. wiwi . uni-hannover . de/Forschung/Diskussionspapiere/dp-530.pdf

Kaldor, Nicholas. 1961. 'Capital accumulation and economicgrowth' in The Theory of Capital edited by Friedrich Lutz and Doughlas C. Hague, 177?222. London: Macmillan.

Kennedy, Charles. 1964. 'InducedBiasin InnovationandtheTheoryofDistribution.' The Economic Journal 74295: 541- 547.

Leo'n-Ledesma, Miguel. A., PeterMcAdamand Alpo Willman. 2010. 'Tdentifying the Elasticity of Substitution with Biased Technical Change.' American Economic Review 100 4, 1330- 1357. DOI: 10.1257/ aer.100.4.1330

Marx, Karl. 1991. Capital: Volume III. Penguin Books.

MacKinnon,J ames G. 1996. 'Numerical distribution functions for unitroot and 
cointegration tests.' Journal of Applied Econometrics 116: 601- 618.

Pasinetti, Luigi L. 2003. 'Comments: CambridgeCapital Controversies.' Journal of Economic Perspectives 174: 227- 235.

Piketty, Thomas. 2014. Capital in the Twenty-First Century. Cambridge and London: Harvard.

Piketty Thomas and Gabriel Zucman. 2013. “Capital Is Back,” Working Paper Version at http://piketty. pse. ens. fr/files/Piket tyZucman2013WP. pdf, and publishedas: ThomasPikettyandGabrielZucman. 2014. 'Capital isBack: Wealth-Income Ratios in Rich Countries 1700-2010.' The Quarterly J ournal of Economics 129 3, 1255-1310. DOI: 10.1093/ qje/ qju018 Their dataareavailableat ht tp : / piketty . pse.ens.fr/en/capitalisback

Randall, Alan and Emery N. Castle. 1985. 'Land Resources and Land Markets.' In Handbook of Natural Resource and Energy Economics, edited by Allen V. Kneese and J ames L. Sweeney, 571-620. Amsterdam: North-Holland.

Ricardo, David. 1951[1821]. On the Principles of Political Economy and Taxation. The Works and Correspondence, Vol. 1. eds. Piero Sraffa and Maurice Dobb. Indianapolis: Liberty Fund.

Rognlie, Matthew. 2014. 'A note on Piketty and diminishingreturns to capital.' http://wWw.mit.edu/_mrognlie/piketty_diminishing_returns.pdf

Rowthorn, Robert. 2014. 'A Note on Thomas Piketty's Capital in the TwentyFirst Century.' Cambridge Journal of Economics 38 5: 1275- 1284.

Schumpeter, J oseph A. 1954. History of Economic Analysis. London: Allen and Unwin. 
Smith, Adam. 1904[1776]. 'An Inquiry into theNatureand CausesoftheWealth of Nations.' ed. E. Cannan. London: Methuen.

Stiglitz, J oseph. 1974. The Cambridge-Cambridge Controversy in the Theory of Capital; A View from New Haven: A Review Article. Journal of Political Economy 82 4: 893-903.

Taylor, Lance. 2014. The Triumph of the Rentier? Thomas Piketty vs. Luigi Pasinetti and J ohn Maynard Keynes.' 433: 4- 17. DOI: 10.1080/ 08911916.2014.1002296

United Nations, European Commission, International Monetary Fund, Organisation forEconomicCo-operation and Development and World Bank. 2009. System of National Accounts. New York.

\section{Data Appendix}

The data seriesin Table2 aretaken from ht tp ://piketty . pse . ens . fr/en/capitalisback

Table2: Sources files for data series used

Wealth/Net Income (W/X)

Capital/Net Income (K/X)

Net Capital Share excl. gov't interest $\alpha$
AppendixTables.xls sheet Table A1

AppendixTables.xls sheet Table A22

[country].xls sheet Table 11a

For theUK gross computations I used gross national income as well as the sums of components of gross wealth and profit shares that are tabulated in UK.xls in the sheets DataUK1 and DataUK3. 


\section{Mathematical Appendix: Deriving the Equation for Estimation}

The equation to be estimated can be derived both from a CES production function Assuming with Piketty that output, $X$, comes from a CES production function with inputs K and L, and the elasticity of substitution, $\sigma$, the CES functional form is

$$
X=\square d \underline{(\rho K)^{\frac{\sigma-1}{\sigma}}+(1-d)(\xi L)^{\frac{\sigma-1}{\sigma}}} \underline{\Omega}^{\sqcup \frac{\sigma}{\sigma-1}}
$$

where $d \in(0,1)$ is a distribution parameter that determines therelativeimportance of each factor in production and $\rho$ and $\xi$ are productivities. Assuming that factors are remunerated equal to their marginal products, the remuneration of capital or rate of return, $r$, is

$$
\begin{aligned}
\frac{\partial X}{\partial K} & ={ }^{[\Omega]_{\sigma} \frac{\sigma}{T}-1}{ }^{-\sigma_{\mathrm{d}}} d \rho(\rho K)^{\frac{\sigma-1}{\sigma}-1} \\
& =X^{\frac{1}{\sigma}} d \rho(\rho K)^{\frac{-1}{\sigma}} \\
r & =d \rho^{\frac{\sigma-1}{\sigma}} \frac{K}{X}^{\frac{-1}{\sigma}}
\end{aligned}
$$

Writing the marginal product in terms of $K / X$ this gives

$$
\frac{K}{X}=\frac{r}{d \rho \sigma}^{-\sigma}
$$


Taking logarithms gives

$$
\log _{\frac{K}{X}}^{K}=-\sigma \log (r)-\sigma \log (d)-(1-\sigma) \log (\rho)
$$

This expression can beestimated as

$$
\log _{\frac{K}{X}}^{K}=-\sigma \log (r)+c+\varepsilon
$$

where $c$ the constant part of the remaining terms and $\varepsilon$ are possible technology shocks to capital productivity, $\rho$ and to the distribution parameter $d$. In the case of Hicks-neutral technical change thereis a restriction on the technical change parameters that $\rho=\xi$, which can then be collected into the technical change parameter A.

\section{Gross vs. Net Appendix}

Figure 4 shows two plots with pairs of rate of return and thewealth national income (dots) and productivecapital national income(circles) ratiofortheUKfor 1970-2010 and linear fits estimated as in the text body. The left plot displays net national income and the net rate of return, the right plot displays gross national income and gross rate of return. As above, the slopes of the regression lines are the elasticity of substitution estimates times minus one. Gross elasticities are higher than their net counterparts. 
Figure 4: Scatter of annual observations of wealth-income (disks) and productive capital-income(cirlces) ratiosagainst therateofreturn, andlinearfitsfortheUnited Kingdom. The left panel shows wealth and productive capital net of depreciation, theright panel gross of depreciation.

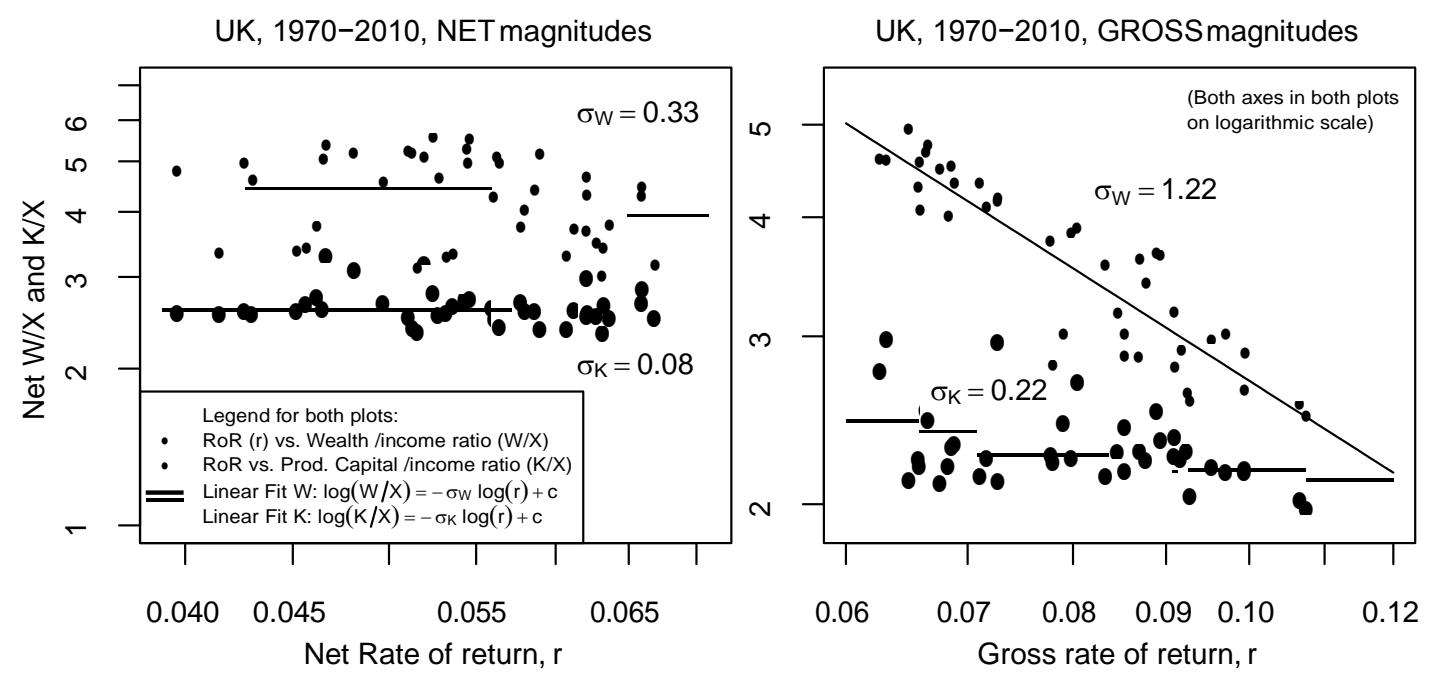

